\title{
René Dubos: Wooing the Earth, from Soil Microbes to Human Ecology
}

\author{
Carol L. Moberg'
}

The Rockefeller University, New York, New York, United States

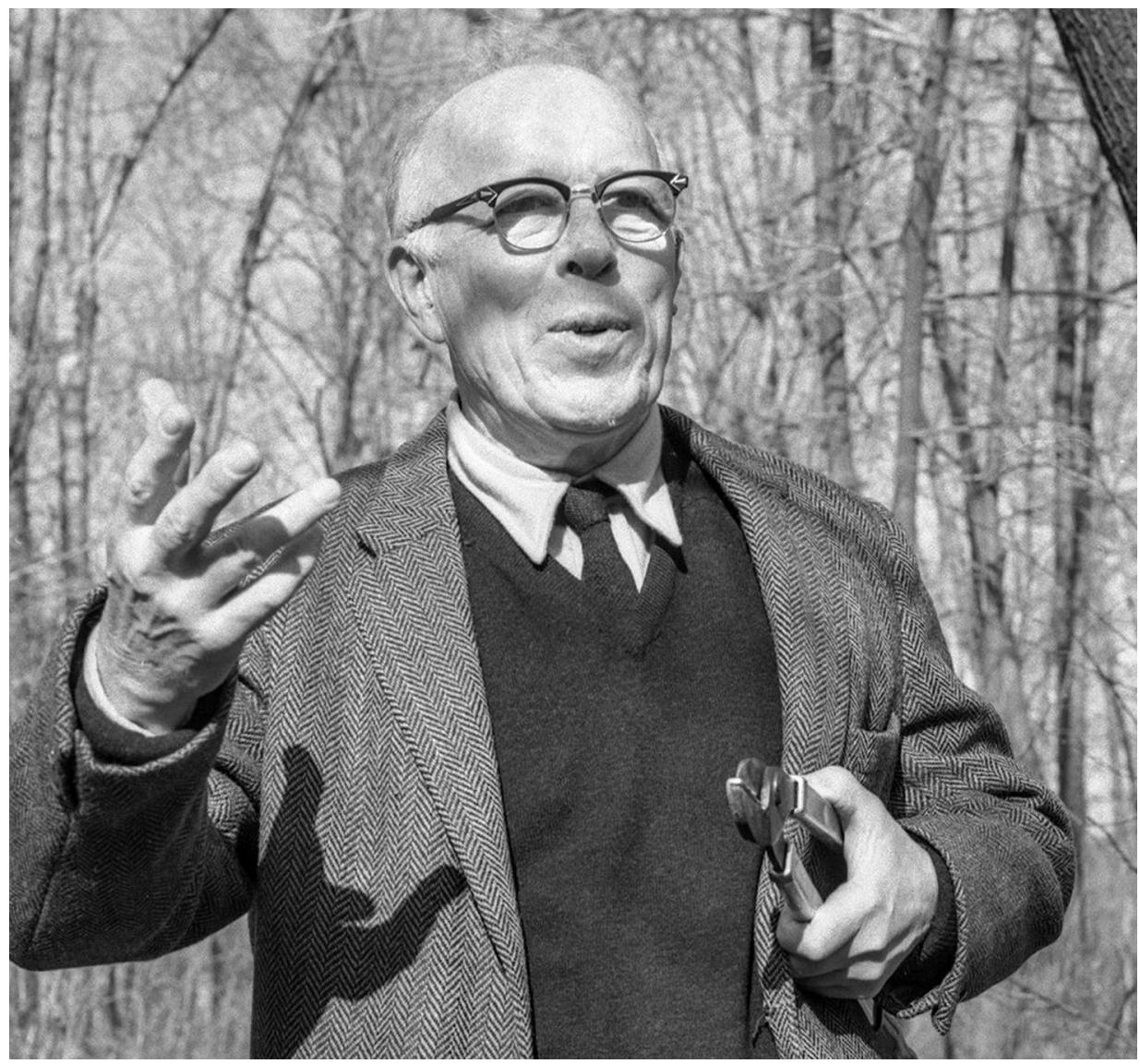

Figure 1: René Dubos at home on the woodland property he restored after buying an abandoned farm, Garrison, New York. 7 April 1972 Source: Photograph (c) Lawrence R. Moberg.

René Dubos was an ecologist from the beginning. He championed the philosophy that a living organism — whether a microbe, human being, society, or the Earth itself - could be understood only in its relationships with everything else (Moberg, 2005). Each stage in Dubos's career broadened his exploration of this philosophy

1 Author contact: moberg@mail.rockefeller.edu 
as he evolved during half a century from studies of soil microbes to promoting a "humanistic biology," in other words, ecology as a humanistic science. Although unknown to Dubos, the term "humanistic science" was not new. In 1922, Ecology, the Ecological Society of America's (ESA) journal, published an article by Stephen A. Forbes, "The Humanizing of Ecology," arguing that economic and humanistic values, with applications of botany, bacteriology, zoology, entomology, and physiology, were all "related to the protection and restoration of health and hence to the prolongation of human life." Of all the biological sciences, Forbes (1922) wrote, ecology is "the humanistic science par excellence" (pp. 90).

For Dubos, the philosophical basis of ecology was health. During his final years, he focused on the human condition and how the world that humans inherit, alter, and leave behind would shape their own health. To him, ecology was not just protecting the environment. It was equally about humans creating something of health, charm, and beauty in their environments. Dubos's views of a human ecology focused on a sense of the possible, the power of vision and creation, and the building of wholesome environments for all of life. Ultimately, just as human health depends on the health of the environment, the Earth's health depends on humans who can change, repair, restore, and create such environments.

\section{Agronomist}

Dubos was born in a French village in 1901 and raised in Paris. He graduated from the National Institute of Agronomy, where one of his favorite courses was the relation of soil fertility to climate. A chance meeting with Selman Waksman in 1924 at a soil congress and his dream for adventures in America led Dubos to pursue a $\mathrm{PhD}$ with Waksman at Rutgers University. He studied which soil microbes decompose cellulose and discovered that the active microbe and its digesting chemical depended on the type of soil in which the cellulose was placed. After presenting these results at an international soil congress, they were published as Dubos's first independent scientific study by Ecology in 1928 .

In 1927, Dubos brought this ecological perspective to the hospital laboratory of Oswald Avery at The Rockefeller Institute for Medical Research in New York City. He isolated an enzyme from a soil microbe that he found in a New Jersey cranberry bog. This enzyme decomposed the cellulose-like capsule of the most virulent strain of pneumonia, allowing white blood cells to destroy the naked bacteria and curing infected animals. Importantly, he discovered the enzyme was produced only when the microbe was grown in a medium that contained the cellulose capsule as its sole source of food. This finding, he said, brought him face to face with one of the most important principles of ecology; namely, that cells have multiple potentialities, which operate only when they are placed in an environment that compels their use. 
When he later applied this biological law of adaptation to human life and behavior, he taught that "each one of us is born with the potentiality to become several different persons but what we become depends on the conditions under which we develop, conditions, furthermore, that are of our own choosing" (Dubos, n.d.).

\section{Medical microbiologist}

In 1939, Dubos became a medical microbiologist and focused on finding a cure for pneumonia. During another systematic soil search, he extracted two substances from the soil bacterium Bacillus brevis, which he named tyrothricin and gramicidin. These were the first natural antibiotics produced commercially on a large scale and used clinically. Within three years-before penicillin and other antibiotics were in general use-Dubos discovered that the bacteria in patients being treated with his antibiotics at Mayo Clinic and elsewhere were becoming resistant to them. Realizing microbes are as adaptable (and resistant) in human bodies as they are in soil, he warned that antibiotics would fail, cause resistance, and set the stage for new diseases (Moberg, 1999). Rachel Carson predicted a "Silent Spring" in warning about DDT. Today, the term "Antibiotic Winter" is being applied to antibiotic resistance for the very reasons given by Dubos more than 70 years ago. Controlling this, he said, will require human, social, and physical environmental changes.

\section{Experimental pathologist}

In 1945, Dubos published his first book, The Bacterial Cell, with a novel theme on the relation of bacteria to disease. Its reception and a personal tragedy-his wife's death from a resurgence of childhood tuberculosis-encouraged him to abandon soil research to pursue another aspect of his ecological philosophy. He speculated that wartime stress and concern for her family in France triggered its resurgence. This alerted him not just to a balance between humans and bacteria, but especially to the impact of physical and mental environments on that balance (Dubos, 1945).

As an experimental pathologist, he turned his studies from isolated microbes to the ecology of infection versus disease. The Dubos laboratory created a culture medium that allowed the first accurate, quantitative studies of mycobacteria and enabled studies of facets of virulence and immunity in tuberculosis. In 1952, acting on his beliefs that infection is the rule, disease is the exception, and prevention is better than cure, he published The White Plague with the subtitle Tuberculosis, Man, and Society (Dubos \& Dubos, 1952). The book's main argument is that throughout history, this disease-which even today infects one-third of the world's population and causes nearly 2 million deaths a year-is influenced by the total environment, including sociological, psychological, and physicochemical factors. 
Weighing evidence from laboratory experiments, Dubos determined that health is an equilibrium in which everyone harbors disease germs, but not everyone is sick. He adopted the Hippocratic view that health is a result of balance in the body and ill-health is a disruption of that balance. In 1959, reflecting his shift in medical thinking, he published Mirage of Health, subtitled Utopias, Progress, and Biological Change, which addressed health from these perspectives. This remains his most popular, influential, and frequently cited book and it is still in print. Viewing infectious disease as an ecologist, he argued that perfect health is utopian and cannot be purchased, measured, or achieved by pursuing one drug or one therapy after another. Health, in his definition, is "not necessarily a state of well-being, not even ... a long life. It is, instead the condition best suited to reach goals that each individual formulates for himself" (Dubos, 1959, p. 233).

\section{Environmentalist}

Renaming his laboratory "environmental biomedicine" in 1961, Dubos enlarged his research to study typical, yet seemingly subtle, environmental stresses on the susceptibility of animals to disease. He tested malnutrition, antibiotics, pesticides, toxins, and crowding, and found each stress increased an animal's susceptibility to disease. When the same stresses were applied to newborn animals, they produced lifelong deleterious effects, a phenomenon Dubos coined "Biological Freudianism" (Dubos et al., 1966). ${ }^{2}$ Other pioneering research revealed the digestive tract is an ecosystem in which intestinal microbes profoundly influence an animal's ability to utilize food as well as to resist various infections and toxins. By showing that microbes are essential for maintaining health, Dubos planted seeds of a new scientific field; the Human Microbiome Project is demonstrating the human body itself is an ecosystem and that changes in our microbial ecology correlate with numerous diseases, some caused by the misuse or overuse of antibiotics. A recent extensive scientific review evaluated some of these discoveries by Dubos concerning the influence of natural environments, nutrition, and microbial ecology on health and disease. The authors analyzed how current research in these areas not only supports but intensifies Dubos's views on human well-being, quality of life, and planetary health (Logan et al., 2005a, 2005b).

Concurrent with his bench experiments, Dubos (1953) began what he called "a philosopher's search for health" to examine diverse environmental manifestations and influences on human life and behavior. In several books and dozens of lectures and essays, he devised various proposals for a novel—and, to some, an impracticalscience devoted to human nature that he named "humanistic biology" (Dubos, 1965a). Research in such a science would identify the formative responses to the

2 A series of retrospective articles on this paper appeared in 2005 in International Journal of Epidemiology, 34, 1-20. 
environment that are organically conditioned by past experiences, social structures, emotional attitudes, and ethical concepts; it would also find ways to show humans how to take a constructive role in creating desirable futures.

As much at home in philosophy and history as in science, Dubos (1968) addressed a mass-market audience in his book So Human an Animal, subtitled How We are Shaped by Surroundings and Events. This timely book appeared just as the popular American environmental movement was emerging. He balanced the alarms about environmental degradation and the dehumanization of mankind with constructive views about how humans could do something to restore their quality of life. The final chapter, "The Science of Humanity," argued for a new ecology to plan for the future by developing human potentialities and pursuing the significance of life, not its mastery. After this book won a Pulitzer Prize in 1969, Dubos became a major public figure during the environmental crusade.

\section{Human ecologist}

Also in 1969, Dubos gave a lecture titled "Human Ecology" to the World Health Assembly, the World Health Organization's highest health policy-setting body, composed of health ministers from all member states. Human ecology, as defined by Dubos (1969), is the scientific expression of biological wisdom; that is, "knowledge of the relationships between man and the innumerable factors of his environment" (p. 499). This lecture introduced the paradox that the apparent ease with which humans adapt themselves biologically, socially, and culturally to civilized life in fact constitutes a real threat to individual well-being and even to the future of the human race. He predicted that the more a population is exposed to modern technology, the more it becomes subject to chronic and degenerative diseases, what he termed "diseases of civilization" (Dubos, 1965b). Human ecology, he concluded, requires a scientific and intellectual attitude to deal with such indirect and long-term effects of environmental forces as the abundance or scarcity of food, pollution, noxious chemicals, noise, overcrowding, and even compulsive leisure.

During his final years, Dubos served as a provocateur who shared the biological wisdom of a human ecologist. He previously had a vigorous public lecture schedule, talking at least once a week to physicians, medical students, and public health and government officials. After receiving the Pulitzer Prize, the size and number of his audiences increased substantially to include students and faculties in liberal arts colleges, universities, environmental organizations, international societies, and local community groups. He reached an enormous number of uncommitted students, committed activists, and concerned citizens, the very people he believed could put into action what he professed in words. Not inconsequently, Dubos during his lifetime received 41 honorary degrees from universities worldwide that sought 
his vision of relating human health to human environments. His audience grew even wider following numerous television and radio interviews related to the first Earth Day in 1970 and, two years later, to the first United Nations Conference on the Human Environment in Stockholm. Walter Cronkite (1997), iconic anchorman of CBS News, wrote in his autobiography that his interview with Dubos was, in his words, "the most provocative of my career" (p. 285). Cronkite was asking "Can the World be Saved?" to which Dubos provided optimistic and creative ways that humans could change conditions before the crises occurred.

Compared to other prominent scientists, such as Margaret Mead, Linus Pauling, Paul Ehrlich, and Barry Commoner, Dubos stood alone, in part because he was much older and less controversial. These credible scientists were attractive for their hot or controversial topics, maverick or iconoclastic status, and colorful images. While often interacting with them, Dubos remained distinct by deliberately not discussing political issues. On scientific and technological matters, he offered social rather than technical comments by advocating that solutions to environmental problems would also need organizations, methods, and social forces that were currently outside established traditions and structures. This did not keep him from being effective. He spoke in a questioning, almost conversational manner, rather than a dogmatic one. With an eloquent flow of stories told with a gentle French accent and avuncular charm, he could move audiences to laughter, anger, tears, and routine standing ovations. He masterfully implied, without ranting, that if his concerns were as important to them as they were to him, they should also become involved. There were constant, gentle reminders of collective responsibility for offences against the environment in biologically based "sermons," such as how "we must learn," "we must identify," "we must limit," or "we must change our ways of life" by developing positive values.

Trying to summarize Dubos's broad visions of human ecology is comparable to a comment by Hobart Lewis, the long-time editor of Reader's Digest. He once introduced Dubos by saying he had spent his entire life digesting the work of others but found it impossible to reduce the richness of Dubos's work to a few ideas or pages. Fortunately, Dubos was a master phrase-maker who coined many aphorisms to simplify vast messages, many of which are also the titles of his two dozen books. Here are just four: "despairing optimist," "where humans are concerned, trend is not destiny," "improving on nature," and "think globally, act locally."

\section{Despairing optimist}

In 1970, Dubos assumed a distinct persona and characterized himself in his columns for the American Scholar as a "despairing optimist." His despair was that the real environmental tragedy was the progressive degradation and dehumanization 
of life due to our failure to see ourselves as integral parts of the Earth's ecosystem. His optimism lay in his faith in the resiliency of nature and creative adaptations of human beings to undo the damage they had wrought.

\section{Where humans are concerned, trend is not destiny}

Other environmentalists were describing future scenarios of vanishing wilderness, depleted resources, approaching famine, species extinction, population bombs, energy shortages, greenhouse gases - in short, doomsday predictions. Dubos argued instead that these trends were not destiny but symptoms of a much larger affliction that was not the destruction of life but its progressive degradation, and not death but a worthless human existence. Unlike the doomsayers, he contended there is no longer such a thing as a natural ecology because humans have changed everything in nature, and that people's choices profoundly influence the downward environmental trends.

\section{Improving on nature}

Dubos offered a new and, to many, greatly contested insight that nature does not really know best. Pointing out that much of what we think of as nature is manmade and many of the world's most admired environments are products of human activity, he made clear that improving the environment depends on ecological wisdom and social will. Whether he advocated open horizons, village atmospheres, or natural surroundings to intensify human encounters, or specified changing agricultural patterns, creating safer chemicals, planting more interesting trees, or removing unecological lawns, the message was the same: cultivate environments to nourish such human biological needs as tranquility, beauty, involvement, fertility, and inspiration.

Dubos considered himself a kindred spirit of conservationist-ecologist Aldo Leopold, whose land ethic stated that "a thing is right when it tends to preserve the integrity, stability, and beauty of the biotic community" (Leopold, 1949, pp. 224-225). However, Dubos went further to say that this ethic does not rule out the transformation of nature but was rather another form of improving on nature. Just as Leopold planted lots of trees to heal his abandoned farm, so for three decades Dubos had been rebuilding a diverse healthy landscape by planting trees on his 90-acre worn-out farm in the Hudson River Highlands. Just as Leopold (1991) defined conservation, or land health, as a "positive exercise of skill and insight, not merely a negative exercise of abstinence or caution" (p. 257), so Dubos defined the human counterpart of conservation or health as making creative adaptations; that is, by cultivating the healthy functioning of living organisms, whether animals, plants, humans, landscapes, or communities. 


\section{Think globally, act locally}

Without a doubt the most famous maxim of the twentieth-century environmental movement, this phrase emerged as the world moved from the local euphoria of the first Earth Day to the global environmental challenges considered at the 1972 United Nations Conference on the Human Environment. British economist Barbara Ward and Dubos (1972) prepared the conference's conceptual framework, called Only One Earth: The Care and Maintenance of a Small Planet. In a lecture Dubos (1973) gave at an unofficial forum during the Stockholm conference, he said:

In practice a global approach is needed when dealing with the problems of the spaceship earth which affect all of mankind. But local solutions, inevitably conditioned by local interests, are required for the problems peculiar to each human settlement. (p. 42)

The actual four-word motto first appeared six years later, in a 1978 EPA Journal interview (Temple, 1978).

This iconic phrase spread so quickly and universally that very few people know that it originated with Dubos. It galvanized innumerable crusades by grassroots activists, nature organizations, and political campaigns and continues to proliferate on bumper stickers, billboards, lapel buttons, and tee-shirts. "Think globally, act locally" was used sparingly by him, although he enhanced its ethical implications in his penultimate book, The Wooing of Earth, in 1980. He wrote:

Ecology is nothing more than the study of interrelationships between living things and their environment; it is therefore ethically neutral. These relationships, however, are always influenced by the human presence, which introduces an ethical component into all environmental problems ... ecological thinking must be supplemented by humanistic value judgments. (Dubos, 1980, p. 157)

When this book was translated into French, it won the Prix Littéraire Eugène Le Roy. At the award ceremony, French President Valéry Giscard d'Estaing saluted Dubos in person for espousing an "écologie civilisatrice" and remarked that ecology was no longer only a defensive effort but now a civilizing force "where nature needs man who can alone reestablish the natural equilibrium compromised sometimes by his own actions" (Giscard d'Estaing, 1980). ${ }^{3}$

The important legacy of Dubos's human ecology in "Think globally, act locally" resides in its spirit of practicality infused with a sense of environmental citizenship. Between abstract awareness and concrete action, between imagination and experience, lay its decree that Earth housekeeping and Earth health begin with human beings. Local was not necessarily a place; it was also Dubos's way of saying 
that what seems small and personal can have profound implications, and that what seems right is worth doing. For this reason, the motto's concept remains practical and empowering.

As much as any individual of the twentieth century, Dubos became the conscience of health. His ability to think ecologically allowed him to accept and expect nature's changes, grasp its complexities, and fathom paradoxes in health and disease. With broad vision, he conceived of a human science of ecology in which human health is symbiotic with the Earth's health, and both had to be evaluated in light of human needs, tastes, and aspirations. Reaching beyond conventional gloom with heartening belief in diversity, resilience, and innovation, he suggested ways to preserve, enrich, and create healthy individuals and environments. The essential biotic view of humans and Earth, to rephrase his grand motto, is think ecologically, act ethically. To whichever ecosystem Dubos applied his thinking, his integrative wisdom focused on seeking health. As a good doctor, he practiced and preached ecology as a healing art.

\section{References}

Cronkite, W. (1997). A reporter's life. New York, NY: Knopf.

Dubos, R. J. (1928). Influence of environmental conditions on the activities of cellulose decomposing organisms in the soil. Ecology, 9, 12-27. doi.org/ $10.2307 / 1929538$

Dubos, R. J. (1945). The bacterial cell in its relation to problems of virulence, immunity and chemotherapy. Cambridge, MA: Harvard University Press.

Dubos, R. J. (1953). The philosopher's search for health. Transactions of the Association of American Physicians, 66, 31-41.

Dubos, R. J. (1959). Mirage of health: Utopias, progress, and biological change. New York, NY: Harper.

Dubos, R. J. (1965a). Humanistic biology. American Scientist, 53(1), 4-19.

Dubos, R. J. (1965b). Man adapting. New Haven, CT: Yale University Press.

Dubos, R. J. (1968). So human an animal: How we are shaped by surroundings and events. New York, NY: Scribner.

Dubos, R. J. (1969). Human ecology. WHO Chronicle, 23, 499-504.

Dubos, R. J. (1973). Unity through diversity. In M. Strong (Ed.), Who speaks for Earth? (pp. 33-42). New York, NY: W.W. Norton. 
Dubos, R. J. (1980). The wooing of Earth. New York, NY: Scribner.

Dubos, R. (n.d.). The effects of events, surroundings and personal choices on the scientific interests and attitudes of René Dubos at age 1981 [36 typescript pages]. René Jules Dubos Papers, The Rockefeller Archive Center, Box 31, Folder 14.

Dubos, R., \& Dubos, J. (1952). The white plague: Tuberculosis, man, and society. Boston, MA: Little Brown.

Dubos, R., Savage, D., \& Schaedler, R. W. (1966). Biological Freudianism: Lasting effects of early environmental influences. Pediatrics, 38(5), 789-800.

Forbes, S. A. (1922). The humanizing of ecology. Ecology, 3(2), 89-92. doi.org/ $10.2307 / 1929143$

Giscard d'Estaing, V. (1980). L'écologie objectif de civilisation. Environnement et Cadre de Vie, 13, 6-11.

Leopold, A. (1991). The farmer as a conservationist. In S. Flader \& J. Callicott (Eds.), The River of the Mother of God: and Other Essays by Aldo Leopold. Madison, WI: University of Wisconsin Press. (Original work published 1939)

Leopold, A. (1949). Sand County almanac. New York, NY: Oxford University Press.

Logan, A. C., Katzman, M. A., \& Balanzá-Martínez, V. (2005a). Natural environments, ancestral diets, and microbial ecology: Is there a modern "paleodeficit disorder"? Part I. Journal of Physiological Anthropology, 34(1), 1-18. doi.org/10.1186/s40101-015-0041-y

Logan, A. C., Katzman, M. A., \& Balanzá-Martínez, V. (2005b). Natural environments, ancestral diets, and microbial ecology: Is there a modern "paleodeficit disorder"? Part II. Journal of Physiological Anthropology, 34(9), 1-21. doi.org/10.1186/s40101-014-0040-4

Moberg, C. L. (1999). René Dubos, a harbinger of microbial resistance to antibiotics. Perspectives in Biology and Medicine, 42(4), 559-580. doi.org/ $10.1353 / \mathrm{pbm} .1999 .0011$

Moberg, C. L. (2005). René Dubos, friend of the good Earth. Washington, DC: ASM Press.

Temple, T. (1978). Think globally, act locally. EPA Journal, 4(4), 4-11.

Ward, B., \& Dubos, R. (1972). Only one Earth: The care and maintenance of a small planet. New York, NY: W.W. Norton. 
This text is taken from Human Ecology Review, Volume 23, Number 2, 2017, published 2017 by ANU Press, The Australian National University, Canberra, Australia.

dx.doi.org/10.22459/HER.23.02.2017.07 